10.53116/pgaflr.2018.2.5

\title{
Designated Income Accounts in Budgetary Units of Municipalities as a Form of Partially Decentralised Redistribution of Public Finance Resources Allocated to Educational Services in Poland
}

\author{
Zbigniew Ofiarski*
}

\begin{abstract}
* Zbigniew Ofiarski, Full Professor, Head of the Department of Finance Law, Faculty of Law and Administration, University of Szczecin, Poland. Author of over 550 publications, including 38 books (monographs, students' books, and commentaries), articles, studies in joint works and electronic publications. He is a member of the Centre of Information and Organization of Public Finances and Tax Law Research in Central and Eastern Europe. (e-mail: zbigniew.ofiarski@usz.edu.pl)
\end{abstract}

\begin{abstract}
The Act of 27 August 2009 on public finance, which has been in effect in Poland since the beginning of 2010, has changed the rules regarding the keeping of designated income accounts by a commune's budgetary units. The Act limited the possibility to create designated income accounts within a commune budgetary units. The right to create such accounts is restricted only to budgetary units which perform educational tasks and is an exception from the principle of full budgeting, a principle meaning that a commune's budgetary units have to transfer all their income to the commune's budget, and all expenses of budgetary units are covered from the commune's budgets. In case of educational services, these public tasks are performed by the commune's budgetary units as organizational units that are most closely linked with the commune's budget. An exception here, which is an option at the discretion of the Commune's Council, is to create a designated income account within the commune's budgetary unit.

The aim of the paper is to analyse and evaluate relevant legislation, judicial practice of courts and regional accounting chambers, as well as the doctrine of administrative law, in particular, educational law and public finance law regarding the scope of applicability of designated income accounts for a commune's budgetary units that perform educational tasks. The hypothesis that the financing of such expenses through a designated income account is a special form of redistribution of public financial resources in a commune was proven correct. The implementation of this form of funding is justified by the nature of public educational services and allows for more efficient management of this part of public finance. The leading method applied in the paper was the dogmatic and legal method, supported by the empirical and analytical method (in particular with regard to the judicial practice of courts and regional accounting chambers).
\end{abstract}

Keywords: commune; education; budgetary unit; public educational services; designated income account

\section{Introduction}

In the Polish public finance sector, there are various methods of settling the accounts of this sector's organisational units with the respective budget. In accordance with the 
criterion of the manner of settlement, the individual organisational and legal forms, regulated in the Public Finance Act of 27.08.2009, ${ }^{1}$ may be divided into two groups. ${ }^{2}$ The first one is created by budgetary units settling with the so called gross method, i.e. covering their spending directly from the budget and transferring the income obtained into the account of the state budget or the budget of a local government unit. The second group includes organisational units settling with the budget with the so called net method (e.g. local government budgetary establishments), i.e. through payment of a part of the surplus current assets.

In the catalogue of the organisational and legal forms of the public finance sector, there are also such that are devoid of the value of organisational separation. Their feature is separation of a planning and financial nature, but they are used within a specific organisational structure. They are forms of a mixed or even hybrid nature. This category may include a designated income account, which may be created in a budgetary unit.

The aim of this paper is the analysis and evaluation of the normative material, decisions of courts and regional accounting chambers, the achievements of the administrative law doctrine, including the public finance law concerning the permissible scope of using the designated income account in budgetary units as a method of gathering public financial resources from specific sources and financing of expenses in a municipal budgetary unit (performing educational tasks) with partial omission of the municipal budget. The paper verifies the hypothesis that the possibility of financing specific expenses from a designated income account is a special form of redistribution of public financial resources in a municipality. The introduction of this form is justified with the specificity of public services performed in the sphere of education and enables more effective management of a part of public financial resources. The municipal council decides about the possibility of using this form relatively freely. The paper uses the dogmatic and legal method as the dominant one as well as, additionally, the empirical and analytic one (in particular with regard to the decisions of courts and regional accounting chambers).

\section{The Genesis of Designated Income Accounts - The Outline of the Problem}

Pursuant to Article 223 of the PFA, designated income accounts may be established in local government (i.e. municipality, powiat and voivodeship) budgetary units. The financial management of budgetary units is strictly connected with the respective budget because a budgetary unit, as an organisational unit of the public finance sector without legal identity, pursuant to the provisions of Article 11 of the PFA, covers its expenses directly from the budget, whereas its obtained income is transferred to the respective budget. It is an important concept of the so called gross budgeting, which has both its advantages and disadvantages. The advantage is, first of all, more transparency and completeness of managing public resources facilitating consolidation of these resources within a specific budget. The disadvantage is lack of relations between the financial result of the activity conducted in the budgetary unit and the system of motivating its employees to more effective management of public financial resources. ${ }^{3}$ 
It is necessary to introduce specific solutions which will provide a budgetary unit with a share in some of the obtained incomes through a possibility of financing selected types of expenses. Various solutions have been sought in Poland within this scope for many years. In the period when the Public Finance Act of 30.06.2005 was in force, ${ }^{4}$ motivation funds were established in state budgetary units intended for gathering of some of the incomes obtained from forfeiture of objects or financial benefits resulting from revealing of crimes and offences against property or tax crimes and offences. Motivation funds were intended for rewards for employees, soldiers and officers who directly contributed to obtaining of the state budget incomes for the above mentioned reasons. Moreover, budgetary units could keep some of the incomes obtained from specific sources (e.g. fees for access to tender documentation, compensations for lost or damaged property) with a view to financing of certain expenses indicated in the act (e.g. for renovation or recreation of property). To this end, designated own income accounts were created in budgetary units. In this manner, the gross budgeting method was partially abandoned and elements of net budgeting were introduced into the budgetary unit. ${ }^{5}$

Currently, designated income accounts used in Poland are a continuation of the concept referring to special resources of budgetary units (a budgetary unit retained a part of the incomes for its own needs and could spend them on the purposes listed in the act), introduced in 1958 and abandoned in 2004, and, then, the above mentioned motivation funds as well as designated own income accounts. It must be emphasised that modern solutions involving the use of designated income accounts are limited within the objective scope. They may be used in state and local government budgetary units, but only such that conduct the activity in the field of education. Further deliberations in this paper shall focus on the problem matter of creation and functioning of these accounts in municipal budgetary units.

\section{Statutory Criteria Concerning the Establishment of Designated Income Accounts}

The provisions of Article 223 of the PFA explicitly indicate that a designated income account may be created in an already existing budgetary unit. This means that the order of legal events should be as follows: establishment of a budgetary unit and, then, creation of a designated income account within the unit. It is possible to establish a budgetary unit and create a designated income account within it in a single legal act because, in each of these cases, the same authority has the legislative competences. As regards a municipality, this is its decision making and regulatory body, i.e. the municipal council.

Designated income accounts may be created not only in municipal budgetary units which conduct the activity specified in the Act of 14.12.2016 - School Education Law. ${ }^{6}$ Pursuant to Article 11(2) of the Act, the provision of education, upbringing and care, including special education and social prophylaxis, is an educational task of a municipality in pre-schools and other forms of pre-school education as well as primary schools. These are the municipality's own tasks of an obligatory nature. Pre-schools and primary schools are organised in the form of municipal budgetary units. ${ }^{7}$ This is the only permissible 
organisational and legal form, which is directly stipulated in Article 4(1) of the Act of 27.10.2017 on Financing of Educational Tasks. ${ }^{8}$ Pursuant to this provision, pre-schools and schools established and operated by local government units are budgetary units.

The creation of designated income accounts in such budgetary units performing educational tasks is not obligatory. The solution in this case depends on the scope of competence of the municipal council. The scope of the municipality's freedom of decision is relatively wide because Article 223(1) of the PFA mentions only example types of incomes which may be paid into a designated account created in a municipal budgetary unit conducting educational activity. The open catalogue of these incomes is determined by the phrase "in particular" used in the content of the provision. The legislator indicated the following types of incomes: inheritances, legacies and donations in the form of money for the benefit of the budgetary unit; compensations and payments for lost and damaged property managed or used by the budgetary unit. Based on the above quoted provision of the Act, the municipal council determines, by means of a resolution, the sources from which the incomes are gathered in a designated income account. The details and the closed catalogue of the sources of incomes which may be gathered in such accounts, as well as their intended purposes should be specified in a resolution of the municipal council. ${ }^{9}$

The catalogue of issues which the municipal council should regulate in the resolution on creation of a designated income account is also closed. The list of these issues is preceded by the phrase "in particular". This means that, except for the issues mentioned directly in Article 223(2) of the PFA, the municipal council may also include other provisions. It may be concluded that the issues mentioned in the Act are of basic nature and are directly related to the legislator's concept referring to the designated income account. Therefore, the municipal council should primarily specify the following in the resolution concerning the designated income account:

a) the municipal budgetary units which gather the incomes

b) the sources from which the incomes are gathered in the designated income account

c) the intended purposes of the incomes; however, the incomes together with interest shall not be allocated to financing of personal remunerations

d) the manner and procedure of preparing the financial plan of the incomes and expenses financed with them, the introduction of changes in the plan and their approval

The wording of Article 223 of the PFA clearly indicates that it is only the resolution of the municipal council that should indicate e.g. the municipal budgetary units, i.e. individualise the entities which will gather incomes in the designated income account, as well as determine the specific sources of these incomes. It is not possible to be limited only to a general reference to the Public Finance Act or a repetition of the provision of the Act the more so that the legislator, while mentioning the sources of incomes in Article 223(1) of the PFA, used the phrase "in particular" and, thus, only indicated some example sources of incomes. ${ }^{10}$ Nevertheless, it cannot be pretended that each type of income may be gathered in a designated income account. This does not mean that such incomes should be qualified from the point of view of the sources mentioned in Article 223(1) of the PFA, taking into consideration their one-off or exceptional nature. The criteria should not be referred to the 
nature of the sources within the meaning of their singularity or uniqueness, but to the legal possibility of obtaining them by the municipal budgetary unit with additional inclusion of the nature of its activity in the educational sphere. ${ }^{11}$

The analysis of the content of selected municipal council resolutions indicates a relatively extensive catalogue of income sources, which may be gathered in designated income accounts of municipal budgetary units conducting educational activity. The following sources of income are mentioned: cash inflows from inheritances, legacies and donations in the form of money for the benefit of a budgetary unit; contributions from compensations and payments for lost or damaged property managed or used by a budgetary unit; incomes obtained from rental of spaces and devices; interest on the resources gathered in the bank account; payments for using of the gym, sports field and sports equipment; payments for using of computers, other devices and equipment; payments for organisation of leisure activities for children and youth during winter and summer holidays; cash inflows from other services; ${ }^{12}$ payments for meals; payments for children staying in a pre-school; ${ }^{13}$ cash inflows from the sale of tangible assets; ${ }^{14}$ extra-budgetary resources obtained from foundations, associations and other institutions for implementation of programmes. The sources of income shall be specified in a specific manner in the resolution. It is not permissible to indicate, in a resolution of the municipal council, any source of incomes of the designated account as "other contributions". The use of such a manner of regulation means that no source has been specified for incomes which may be gathered in the account and results in the head of the budgetary unit being able to decide about the incomes which will credit the designated income account, whereas Article 223 of the PFA leaves the specification of the sources of incomes to the competences of the municipality. ${ }^{15}$

The municipal council resolution should also determine the intended purpose of the incomes gathered in a designated account. The legislator, nevertheless, excludes the possibility of allocating these incomes together with interest to financing of personal remunerations. The above quoted resolutions of municipal councils determine various types of expenses which may be financed from designated income accounts, e.g.: the purposes indicated by the donor; renovations of buildings administered by the municipal budgetary unit; investment expenses; expenses related to recreation of damaged or lost property; purchases of cleaning agents; purchases of food; purchases of equipment for kitchens and canteens; statutory tasks of the budgetary unit; expenses related to the bank operation of the designated income account; other purposes directly related to the activity of the budgetary unit.

The intended purpose of the resources from the designated income account should be specified in a resolution of the municipal council in a precise and exhaustive manner so that there are no doubts as to which expenses the head of a budgetary unit may allocate the incomes gathered in the account. These conditions are not fulfilled by the phrase used in a resolution pursuant to which "current expenses" may be financed from the designated income account, because one of such expenses is personal remunerations which shall not be financed from this account as it has been stipulated by the legislator in Article 223(2) (3) of the PFA. ${ }^{16}$ For the same reasons, it is not permissible to include, in a municipal council resolution, phrases about a possibility of financing "other purposes directly related to the activity of the budgetary unit" or "statutory tasks of the budgetary unit" from the 
designated income account. Neither is it appropriate to include, in a resolution, any phrase saying that expenses of a budgetary unit which are not covered by the financial plan of the unit would be financed for the designated income account. This would lead to the violation of the essence of a budgetary unit determined in Article 11(1) of the PFA and Article 52(1) (2) of the PFA, which stipulates that the costs included in the annual financial plan of a budgetary unit may be increased if incomes higher than the ones forecast have been obtained and increasing of the costs shall not result in increased subsidies from the budget or an increase in the planned state of liabilities. This would result in the violation of Article 261 of the PFA stipulating that the head of a budgetary unit may, with a view to performance of the tasks, incur financial obligations up to the amount of the expenses determined in the approved financial plan of the unit. Hence, the level of expenses incurred by a budgetary unit does not depend on the amount of incomes obtained (gross budgeting). All expenses of a budgetary unit are budgetary expenses and the incomes obtained by it (as a rule) are budgetary incomes. An exception from this rule, in the form of the designated income account, is introduced by Article 223 of the PFA. Introduction, by a municipal council, of the arrangements as to this type of incomes and their intended purpose shall, nevertheless, not lead to any change in the form of financing of the municipal budgetary unit through creation of the second independent source of financing of its financial plan (remaining outside the municipal budget). ${ }^{17}$

Pursuant to Article 223(3), expenses from the designated income account may be incurred up to the amount of the gathered incomes within the financial plan. This means that the account shall not be credited from other sources which have not been mentioned in the resolution of the municipal council. The statutory phrase "up to the amount of the gathered incomes" does not create any obligation of using all the financial resources gathered in the account. Nevertheless, it should not be interpreted towards arbitrary spending of these resources because each of the expenses should have its basis in the form of being included in the financial plan of the designated income account. An order has been formulated in Article 223(4) of the PFA to transfer the financial resources remaining in the designated income account on 31 December of the financial year to the budget of the municipality. The resources should be transferred not later than by 5 January of the following year. This means that the resources from the designated income account unused in a given year shall not be used further by the specific municipal budgetary unit, even in a situation when they were included in the financial plan of the account but were not used by the end of the financial year. This is a mandatory rule and shall not be modified in any manner through municipal council resolutions.

The obligation to transfer incomes gathered in the designated account to the municipal budget is qualified as an expense from the designated account (payment to the municipal budget). In accordance with the budgetary classification, transferring of the resources remaining in the designated account to the budget is effected pursuant to "paragraph 240 - transfers of the remaining financial resources gathered in a designated account of a budgetary unit into the budget". A payment into the municipal budget constitutes an expense from the designated account and an income within the scope of the municipal budget of the following year. Such payments are not included as current expenses of the municipal budget. ${ }^{18}$ The essential feature of functioning of the designated income 
account is that the unused financial resources remaining at the end of the financial year must be transferred to the municipal budget. The reverse direction of the financial stream, i.e. crediting of the designated income account from the municipal budget is not permitted by the law. To conclude, only complete use of the resources gathered in the designated income account in compliance with the plan results in no obligation to transfer them to the municipal budget.

\section{Legal Status of the Financial Plan of a Designated Income Account}

Pursuant to Article 223(2) (4) of the PFA, a municipal council shall determine, by means of a resolution, the manner and procedure of preparing the financial plan of the designated income account, which shall include the sources of incomes and the expenses financed with them. Pursuant to the same procedure, the municipal council shall determine the manner of introducing changes in the plan and the manner of their approval. It is exclusively the municipal council determining the procedure of introducing changes in the financial plan of the incomes gathered in the designated account and the expenses financed with them that is authorised to indicate the entities entitled to introduce the changes and approve them. The municipal council is, nevertheless, not authorised to transfer the rights to the executive body. ${ }^{19}$ The analysis of the provisions of the selected municipal council resolutions shows that standard solutions are adopted within this scope. Heads of municipal budgetary units, together with projects of financial plans of these units, develop the projects of financial plans of incomes gathered in a designated account and the expenses financed with them. The projects of financial plans are filed with the executive body of the municipality within the time limit enabling their inclusion in the project of the municipal budget resolution. A project of the financial plan approved by the head of the municipal budgetary unit constitutes the basis of financial management within the designated income account in the period from 1 January of the financial year until the date of adopting the budget resolution by the municipal council. Similarly as in the municipal budget, also in the financial plan of the designated income account, the planned incomes constitute a forecast, whereas the planned expenses are the limit. This means that the primarily forecast incomes may be obtained in higher amounts, whereas the planned expenses shall not be incurred in higher amounts unless they are financed from additional incomes and a respective change is introduced within this scope in the financial plan of the designated income account. During the financial year, the financial plans of designated income accounts may be changed by heads of municipal budgetary units.

In order to ensure the planning discipline, municipal council resolutions also specify the dates of preparing the projects of financial plans of designated income accounts and the dates of submitting the information and the reports concerning the implementation of the plans. Determination of such dates enables synchronisation of the mode of project works on financial plans of designated income accounts with the procedure concerning other financial plans in the municipality, including in particular the municipal budget and the financial plans of municipal budgetary units. Therefore, heads of municipal budgetary 
units are obliged to check annually, by 20 October, the financial plan of the designated income account for the following year. Heads of municipal budgetary units are obliged to present the municipal executive body with information on the course of implementation of the plan for the first half of the year by 10 July, whereas, by 31 January of the year following the financial year - an annual report on the accomplishment of the financial plan.

The use by the legislator of the phrase "designated income account" simultaneously indicates its separation from the conventionally understood municipal budget. The phrase "designated income account" means separation of the account from the accounts kept with a view to bank operation of the municipal budget. It is not only a separate financial resource being at the disposal of the head of a municipal budgetary unit, but also a stream of incomes and expenses separated from the municipal budget as regards planning. The financial plan of the designated income account is a planning document separated from the financial plan of the municipal budgetary unit where such an account was created. It should be prepared with the use of all sections of the budgetary classification, i.e. in particular: division, chapter, paragraph in the budgetary classification. Pursuant to the provisions of Article 211(5) of the PFA (specifying the structure of a budget resolution which includes the municipal budget and appendices), as well as Article 212 of the PFA (specifying the so called subject matter of a budget resolution) and Article 214 of the PFA (specifying the content of the appendices to the budget resolution also stipulating that the plan of incomes of a separated income account of municipal budgetary units conducting the activity determined in the School Education Law and the expenses financed with them are included in a separate appendix), it must be explicitly concluded that the financial plan of a designated account of incomes and expenses of a municipal budgetary unit is a planning document separated from the municipal budget, being a municipality planning document, as well as from the financial plan of the municipal budgetary unit. The above mentioned financial plans are only included in the same normative act, which is the municipal budget resolution.

The arrangements adopted in the financial plan of the designated income account of a municipal budgetary unit are arrangements separated from incomes and expenses approved in the municipal budget and the financial plan of a municipal budgetary unit. These are separate categories of incomes and expenses and shall not be treated as synonymous, or interchangeable or aggregated for other purposes determined in separate acts. The above assessment is confirmed in the doctrine of the public finance law. ${ }^{20}$ It is emphasised that the financial plan of the designated income account of a municipal local government budgetary unit reveals significant information not included in the municipal budget concerning non-budgetary management of public resources in a municipality. ${ }^{21}$

Separation of the financial plan of a designated income account from other financial plans adopted in a municipality is also confirmed by the provisions of the PFA concerning budget reporting. Based on the delegation of legislative powers formulated in Article 41(2) of the PFA, the Minister of Finance determined - by means of a regulation ${ }^{22}$ - the types, forms, dates and methods of preparing the reports. The provisions of the regulation explicitly indicate that separate reports are prepared on accomplishment of municipal budgets (reference no. Rb-27S and Rb-28S), as well as on the incomes and expenses in designated accounts of municipal budgetary units (reference no. Rb-34S). Furthermore, 
Article 267 of the PFA indicates that the executive body of a municipality presents to the municipal council, by 31 March of the year following the financial year, an annual report on the accomplishment of the municipal budget containing a statement of incomes and expenses resulting from closing of municipal budget accounts, in the detail not lesser than in the municipal budget resolution. The statement of incomes and expenses should include the data resulting from the closing of municipal budget accounts, as well as the list of budgetary units where designated income accounts have been created (only a list of such municipal budgetary units is mentioned and not the amounts gathered and spent from the designated income accounts). This is another argument justifying the thesis on separation of the municipal budget and the designated income account of a municipal budgetary unit, as well as the financial plan connected with this account.

\section{Final Conclusions}

The applicable legal regulations indicate that the legislator regulates, within the subjective and objective scope, the creation and functioning of designated income accounts. It is permissible to create such designated accounts only in budgetary units conducting a specific type of activity, i.e. performing educational tasks. The principle is performance of public services in the sphere of education with the use of the form of a municipal budgetary unit as the organisational unit most closely connected with the municipal budget. A designated income account shall be treated as an exception from the principle of gross budgeting $^{23}$ (involving transfer of all incomes obtained by a budgetary unit to the municipal budget and covering of all expenses of the budgetary unit from this budget). Although the resources gathered in designated income accounts are included in the general, i.e. municipal budget records and reports, they are at the disposal of the head of a municipal budgetary unit rather than the executive body of the municipality responsible for implementation of the municipal budget. The amount of expenses from the designated income account is limited by the amount of incomes obtained from the sources indicated in the municipal council resolution.

Creation of designated income accounts de facto leads to decentralisation of the competences in the process of gathering and spending of a part of the municipality's financial resources. Municipal budgetary units gather financial resources and finance some specific expenses independently with them, yet within the limits set by the municipal council by means of a resolution. The cash inflows obtained by them owing to their activity are used within their own scope. ${ }^{24}$ It is possible to conclude that the manner of functioning of designated income accounts may have a positive influence on the activity of municipal budgetary units. First of all, it may motivate the managements of these units to obtain additional incomes from sources not related to the main object of activity of the municipal budgetary unit. The additional financial resources obtained in this manner constitute the source of financing the expenses without an excessive burden to the municipal budget. As a result, designated income accounts may lead to improvement of the level of flexibility in conducting of the financial management in a budgetary unit. ${ }^{25}$ 
While adopting the Public Finance Act in 2009, a concept of consolidation of public finances was promoted, as well as the need of maximum limitation of various forms of non-budgetary and semi-budgetary management (e.g. state budgetary establishments and motivation funds were abolished). The possibility of creating own income accounts in (state and local government) budgetary units was significantly limited, the essence of functioning of which was very close to the currently created designated income accounts. In the latter case, this form of conducting the non-budgetary management was, nevertheless, not completely abolished, but rather reorganised through its use only in budgetary units performing educational tasks. ${ }^{26}$

The hypothesis formulated in the introduction, according to which financing of specific expenses from a designated income account constitutes a specific form of redistribution of public financial resources in a municipality has been verified positively. The introduction of this form of non-budgetary management is justified with the specificity of public services performed in the sphere of education and enables more effective management of a part of the public financial resources. In particular, the assets transferred by the municipality into the management of a budgetary unit may be used more effectively and constitute an additional source of incomes in the form of fees collected for leasing of premises, land or sport infrastructure facilities (e.g. gyms, swimming pools and school sports fields, common rooms). This may only happen, nevertheless, after the performance of public educational services. Additional financial resources may be used in order to better meet the needs of the local community in the sphere of education including the obligatory tasks of the municipality. 


\section{References}

1 Journal of Laws of 2017 item 2077 as amended, hereinafter referred to as PFA.

2 Przemysław Panfil, Sektor finansów publicznych, 347, in Andrzej Drwiłło, Podstawy finansów $i$ prawa finansowego (Warsaw, Wolters Kluwer, 2014).

3 Paweł Smoleń, Komentarz do art. 11, 205, in Paweł Smoleń, Ustawa o finansach publicznych. Komentarz [Public Finance Act. Commentary] (Warsaw, C.H. Beck, 2014).

4 Journal of Laws no. 249, item 2104 as amended.

5 Elżbieta Chojna-Duch, Prawo finansowe. Finanse publiczne [Financial Law. Public Finance], 48 (Warsaw, Oficyna Prawa Polskiego, 2017).

6 Journal of Laws of 2018, item 996 as amended.

7 E.g. Resolution of the Town Council in Sochaczew of 14.11 .2017 on granting the statute to Primary School No. 6 in Sochaczew (Official Journal of Mazowieckie Voivodeship of 2017 item 10582); Resolution of the Town Council in Supraśl of 26.02.2018 on establishment of a Local Government Preschool in Grabówka and granting a statute (Official Journal of Podlaskie Voivodeship of 2018 item 1240).

8 Journal of Laws of 2017, item 2203 as amended.

9 Decision of the General Adjudication Committee of 18.06.2012: BDF1/4900/54/54/12/1437.

10 Judgement of the Voivodeship Administrative Court in Gorzów Wielkopolski: I SA/Go 435/11.

11 Judgement of the Voivodeship Administrative Court in Gliwice: IV SA/GI 5/11.

12 E.g. resolution of the Town Council in Drezdenko of 29.11.2011 on gathering of incomes in a designated account by local government budgetary units conducting activity within the scope of education (Official Journal of Lubuskie Voivodeship of 2012 item 133).

13 E.g. resolution of the Mrozy municipal council of 28.10 .2010 on the determination of budgetary units gathering incomes in a designated bank account, the sources of these incomes and their intended purpose, as well as the manner and procedure of preparing a financial plan, introducing changes in the plan and their approval (Official Journal of Mazowieckie Voivodeship no. 216, item 7344).

14 E.g. resolution of the Olszanka municipal council of 29.12.2016 on the determination of budgetary units gathering incomes in a designated bank account, the sources of these incomes and their intended purpose, as well as the manner and procedure of preparing a financial plan of incomes and expenses financed with them, introducing changes in the plan and their approval (Official Journal of Mazowieckie Voivodeship of 2017 item 94).

15 Resolution of the Regional Accounting Chamber in Kielce: 24/11, Official Journal of Świętokrzyskie Voivodeship no. 53, item 655).

16 Resolution of the Regional Accounting Chamber in Poznań: 1/1860/2010, Legalis no. 291413.

17 Resolution of the Regional Accounting Chamber in Wrocław: 76/2010, Legalis no. 315209.

18 Urszula Winkowska-Zakrzewska, Pozostałe na koniec roku środki na rachunku z art. 223 ustawy o finansach publicznych [Resources remaining in the account under Art. 223 of the Public Finance Act at the end of the year], 20, in Wojciech Lachiewicz, Klasyfikacja budżetowa 2018 [Budgetary classification 2018] (Warsaw, C.H. Beck, 2018).

19 Resolution of the Regional Accounting Chamber in Wrocław: 9/2011, Legalis no. 1231961.

20 Joanna Małgorzata Salachna, Komentarz do art. 214 oraz art. 223, 826-828 oraz 877-882, in Eugeniusz Ruśkowski, Joanna Małgorzata Salachna, Finanse publiczne. Komentarz praktyczny [Public finance. Practical commentary] (Gdańsk, ODDK, 2013).

21 Andrzej Gorgol, Komentarz do art. 223, 963, in Pawel Smoleń, Ustawa o finansach publicznych. Komentarz praktyczny [Public Finance Act. Commentary] (Warsaw, C.H. Beck, 2012).

22 Regulation of the Minister of Finance of 09.01.2018 on budget reporting (Journal of Laws of 2018 item 109).

23 Rafał Trykozko, Ustawa o finansach publicznych Komentarz dla jednostek samorzadu terytorialnego [Public Finance Act. Commentary for local government units], 343 (Warsaw, Wydawnictwo Taxpress, 2010).

24 Resolution of the Regional Accounting Chamber in Bydgoszcz: XIX/30/08, LEX no. 1724747. 
25 Paweł Lenio, Rachunki dochodów własnych jednostek budżetowych [Own income accounts of budgetary units], 169, in Prawo Budzetowe Państwa i Samorzadu [State and Local Govenrment Budget Law] no. 1 (2014). https://doi.org/10.12775/PBPS.2014.009

26 Zbigniew Ofiarski, Prawo finansowe [Financial Law], 71 (Warsaw, C.H. Beck, 2010). 